\title{
Economics Consequence of Financial Accounting Standards for Micro, Small and Medium Enterprises
}

\author{
Gagaring Pagalung ${ }^{1}$, Kartini $^{2}$, Amiruddin $^{3}$, Rahmawati $^{4}$ \\ \{gpagalung@gmail.com ${ }^{1}$, hanafikartini@ rocketmail.com ${ }^{2}$, amircici@yahoo.com ${ }^{3}$,rahma_hs@ymail.com ${ }^{4}$ \} \\ Faculty of Economics and Business, Hasanuddin University, Makassar, Indonesia. ${ }^{1-4}$
}

\begin{abstract}
The purpose of the research is to examine deeply how new financial accounting standards of micro, small and medium enterprises (SAK EMKM) can be accepted and implemented by micro, small and medium entreprises in South Sulawesi. The results of this implementation review will produce an overview of how the entrepreneurs react to the emergence of the new SAK EMKM. Research method conducted is to conduct a survey of 40 entities by conducting interviews in-depth and displaying the results of the interviews in the form of an implementation of the object in the in curating Financial statements. Results showed that most of the accounting records performed are very simple in the form of daily accounting records (journals) and even most have not to conduct minimal accounting records such as daily journals. Only one small entity performs complete accounting records in the form of a full financial statement.
\end{abstract}

Keywords:

micro, small and medium enterprises, new accounting standards, microfinance, accounting records

Article Received: 18 October 2020, Revised: 3 November 2020, Accepted: 24 December 2020

\section{Introduction}

The financial accounting standard for micro, small and medium enterprises (SAK EMKM) was published in 2016 by the Indonesian Institute of Accountants (IAI) as the new financial accounting standard which is expected to help micro, small and medium enterprises (MSME) Generates the MSME financial statement. This is important because by knowing the commercial performancethe financial statements-the business, the SMEs can survive and even increase as the purpose of the creation of the company to be able to produce the benefits and welfare of its business owners. SAK EMKM issued by IAI is a guideline for the preparation of financial statements for MSME category which was published in 2016 and useful application as of 01 January 2018. The issuances of the SAK EMKM will be several obstacles in implementing it because it does not necessarily what is in the regulation of SAK EMKM can be known and applied by MSMEs because of some considerations such as many things The new SAK EMKM that is difficult for MSMEs to implement and even at extreme points will be denied the implementation of the SAK EMKM due to various considerations such as economic consideration and capacity of resources owned by MSME Very limited in implementing a new or new regulation such as SAK EMKM. On the other hand, MSMEs certainly needs performance information especially financial performance as in SAK EMKM will be able to produce an MSMEs financial report that is indispensable for MSMEs to know about growing business, in particular, measuring the resulting financial performance so that it can be sustainable. A measurement model of a new accounting standard can be accepted by entrepreneurs in implementing such standards by employers in the company that is known in financial accounting theory called Economic Consequences.

SAK EMKM will be able to help the MSMEs to develop and produce a financial report that is the basis of measuring the financial performance of an MSMEs. The purpose of drafting financial statements is to provide financial position information and performance of an entity that is beneficial to a large number of users in economic 
decision making by anyone who is not in a position can request financial statements, specifically to meet the needs of such information (SAK EMKM, 2016). The financial statement resulting from the implementation of the SAK EMKM is an MSME's financial and performance position. A financial position is a report that shows financial information about an entity's assets, liabilities, and equity on a given date and is presented in a financial position report, while the performance report contains financial performance information of the entity consist of information about earnings and expenses during the reporting period. With the preparation of financial statements of a MSMEs entity based on the accounting standards applicable then the MSMEs have produced measurable financial statements and adhere to the resulting financial regulations, entrepreneurs can also know the business is growing and can be continuous (going concern) and increase the business status of micro-scale enterprises into small-scale enterprises, and even medium-scale enterprises.

Micro, small and medium enterprises (MSMEs) in Indonesia have been regulated in Act No. 20/ 2008 on definitions and criteria called MSMEs. Micro enterprises with less than Rp. 50.000.000 and individual business turnover criteria, while small business with the requirements of net worth amounts up to $\mathrm{Rp}$. 200.000.000,-, and turnover up to Rp. 2.5 billion, on the other hand, the business Medium with a net worth between Rp. 200.000.000 and Rp. 1.000.000.000,-with turnover up to $\mathrm{Rp}$. 50.000.000.000-. With the criteria of net worth and business turnover as stipulated in the MSME, the law has been classified a business can be more advanced and develop along with the capacity of resources owned included in the implementation of the standard Accounting that generates the entity financial statements.

Some of the problems faced by Indonesia in the implementation of MSMEs financial statements such as the availability of human resources to develop SMES financial statements and the extent to which SAK EMKM can be a guideline that can be applied by MSMEs easily and correctly. In addition, MSMEs is expected to develop its business sustainably and adequately. It is hoped that this study will be in-depth with a ' bottom-up ' which is to uncover MSMEs responding well and implement the new SAK EMKM so that MSMEs can thrive and perform well. The direction of the study is to examine a new accounting standard produced by the standard-producing authority of MSMEs accounting standards can be responded and used by MSMEs entrepreneurs. Therefore, the main focus of this research is to know that a SAK EMKM can be understood and practced in the implementation of the financial report preparation of MSMES entities in the province of South Sulawesi.

Hasanuddin University as one of the colleges of PTNBH that has the function of Tri Dharma PT is to conduct research studies that can provide added value and contribute to the country and nation, has proclaimed a research plan ( Renstra Research of Unhas year 2016-2020) which one function is to provide development and implementation direction of superior research with road map with 3 major research themes which one of them is poverty alleviation, Especially on the issue of the development of economic institutions namely (MSMES and cooperatives) has not developed, and the competitiveness and performance of a competitive organization in the global era (Renstra research Unhas 2016-2020). Thus the issue of this research is very relevant to one of the themes that have been proclaimed in the research Renstra of Unhas, i.e., the study of MSMEs institutions concerning the measurement of MSMEs financial performance which in turn will be able to compete in the era Global. The purpose of this research is to know the MSMEs response to the issuance and the enactment of the new financial accounting standards in generating MSME financial statements. Also, to see the implementation of the barriers of MSMEs entities in implementing the SAK EMKM.

Based on the above background, the problem is formulated in this research where MSMEs 
entities can implement the new Financial Accounting Standards (SAK EMKM) in generating MSMEs financial statements and obstacles faced Implemented by MSMEs in implementing SAK EMKM?

\section{Literature Review}

This research was conducted to obtain an overview of the study of an individual MSMEs response to the new published financial accounting standards and any obstacles or constraints experienced by MSMEs in implementing The new standard. Some economic studies of the consequences and implementation of these new standards are applicable in some countries including Bing Xi Du (2018); Justice (2017); Olowe (2013) and Trombetta (2017) in the country of Nigeria, Ghana and China.

Research examining the microfinance revolution on each model of microfinance management and innovation developed, especially on Grameen Bank Microfinance pioneered by Muhammad Yunus has evolved and become a reference and model Development of microfinance in the world. The role of micro and MSME finance as a new alternative to development and simulation of economic growth in the developing country of Khavul (2010). In addition, the practices of micro-economic development in various countries such as Bangladesh with Grameen Banknya, Banco Sol in Bolivia, Compartamos in Mexico, and Enterprises Development Group in Washington D. C USA (Sengupta and Aubuchon , 2008). Other microfinance research that examines the selection of microfinance combinations from the perspectives of customers and microfinance institutions to the perspective of agencies and contracts as well as regulations that are in the development of microfinance (Cull, Kunt, and Morduch, 2009). The overall model of microfinance is a financial instrument or instrument that is a stimulus to economic development and has an impact on poverty reduction and revenue equality.

\section{Research Method}

This research was conducted to obtain an overview of the study of an individual MSMEs response to the news published financial accounting standards and any obstacles or constraints experienced by MSMEs in implementing The new standard. Some economic studies of the consequences and implementation of these new standards are applicable in some countries, including Bing Xi Du (2018); Justice (2017); Olowe (2013) and Trombetta (2017) in the state of Nigeria, Ghana and China.

Research examining the microfinance revolution on each model of microfinance management and innovation developed, especially on Grameen Bank Microfinance pioneered by Muhammad Yunus has evolved and become a reference and model Development of microfinance in the world. The role of micro and MSME finance as a new alternative to development and simulation of economic growth in the developing country of Khavul (2010). Besides, the practices of microeconomic development in various countries such as Bangladesh with Grameen Banknya, Banco Sol in Bolivia, Compartamos in Mexico, and Enterprises Development Group in Washington D. C USA (Sengupta and Aubuchon, 2008). Other microfinance research that examines the selection of microfinance combinations from the perspectives of customers and microfinance institutions to the aspect of agencies and contracts as well as regulations that are in the development of microfinance (Cull, Kunt, and Morduch, 2009). The overall model of microfinance is a financial instrument or instrument that is a stimulus to economic development and has an impact on poverty reduction and revenue equality.

\section{Discussion}

SAK EMKM research uses samples in South Sulawesi, referring to government regulations related to the definition of micro, small, and medium enterprises. A selected sample of 40 businesses with a more dominant proportion to micro-enterprises and small businesses. In detail, 
the examples chosen with the number and shape

following table.

of the company are described according to the

Table 1: Types of Micro, Small, and Medium Enterprises

\begin{tabular}{llcccc}
\hline No & Entities & Amount & \multicolumn{3}{c}{ Types of Enterprises } \\
& & & Individual & CV & PT \\
\hline 1 & Micro & 27 & 25 & 2 & \\
2 & Small & 12 & 8 & 4 & \\
3 & Medium & 1 & & & 1 \\
& Amount & 40 & 33 & 6 & 1 \\
\hline
\end{tabular}

Based on Table 1 shows the selected sample of 40 samples with details of the micro business as much as 27 micro-enterprises with a form of individual business as much as 25 firm and two efforts in the form of a CV. Small business with a total of 12 companies consisting of 8 businesses
Individuals and four attempts in the form of $\mathrm{CV}$, while the medium-sized business of PT is only one business.

Details of the type of business/field in the sector of SMEs are shown in the following table 2:

Table 2: Industries of type of enterprises

\begin{tabular}{llccc}
\hline No & Industries & Micro & Enterprises & Small \\
& & 1 & & Medium \\
\hline 1 & Distributions & 20 & 4 & 1 \\
2 & Cullineries & & 1 & \\
3 & Cosmetics & & 2 & \\
4 & Health & & 2 & \\
5 & Grossir & 6 & 1 & \\
6 & Agribusiness & 27 & 2 & 1 \\
7 & Craft & 27 & 12 & \\
& Amount & & & \\
\hline
\end{tabular}

The type of micro business that amounted to 27 micro-enterprises showed that the distribution business as much as 1 company showed not yet recording, culinary business/services as many as 20 business units shows only 1 enterprise that performs the recording of Statements of profit or cash flow, while the remainder is a record of acceptance and withdrawal of only 8 attempts and 11 business fields do not do the recording. Similarly, the area of craft shows only two attempts to record a daily journal and the remainder as many as four attempts not to register. In detail, micro-business accounting is seen in the following table 3 .

Table 3: Accounting for Mikro Enterprises

\begin{tabular}{llccccc}
\hline No & Industries & Amount & Fin Stat & I/S \& CF & $\begin{array}{c}\text { No Fin } \\
\text { Stat }\end{array}$ & Journals \\
\hline 1 & Distributions & 1 & & & 1 & \\
2 & Cullineries & 20 & 1 & 11 & 8 \\
3 & Craft & 6 & & 4 & 2 \\
& Amount & 27 & 1 & 16 & 10 \\
\hline
\end{tabular}


Table 4: Accounting for Small Enterprises

\begin{tabular}{llccccc}
\hline No & Industries & Amount & Fin Stat & I/S \& CF & $\begin{array}{c}\text { No Fin } \\
\text { Stat }\end{array}$ & Journal \\
\hline 1 & Cullineries & 4 & & 1 & 1 & 2 \\
2 & Cosmetics & 1 & & 1 & & \\
3 & Health & 2 & 1 & & & 1 \\
4 & Grossir & 2 & & & 2 & 1 \\
5 & Agribusiness & 1 & & & 1 & 1 \\
6 & Craft & 2 & & 2 & 5 & 5 \\
\hline
\end{tabular}

The small Entity accounting record as described in table 4 above shows only 1 health entity that conducts accounting reporting in the form of financial statements, while the remaining 11 objects consist of two bodies that conduct Income or cash flow report i.e., culinary and cosmetic business, 5 entities that carry out daily recording of 2 culinary entities, 1 health, 1 leverage, and 1 craft. Five bodies do not perform accounting records in each of the one fields of the culinary, supplier, agribusiness, and handicraft.

For intermediate type entities that have a turnover and enormous wealth indicates only the recording of profit-loss reports as depicted in the following table 5 .

Table 5: Accounting for Medium Enterprises

\begin{tabular}{llccccc}
\hline No & Industries & Amount & Fin Stat & I/S \& CF & $\begin{array}{c}\text { No Fin } \\
\text { Stat }\end{array}$ & Journals \\
1 & PT. Raws Mks & 1 & & 1 & & \\
\hline
\end{tabular}

Overall, all three types of micro, small, and medium entities demonstrate the implementation of accounting records in the form of implementing financial statements based on Financial Accounting Standards (SAK EMKM) is still weak. Micro enterprises accounting records of 27 entities show that no one has performed the complete accounting statement in the form of financial statements, only ten micro-entities that perform simple logging of daily transactions, While the other 16 entities do not even conduct accounting records at all. Similarly, a small object that shows only one body that performs complete accounting records in the form of compiling financial statements. Two entities perform accounting records in the way of generating a loss-of-profit report and or cash flow and five small objects that record daily transaction journals only. There are even five small entities that do not perform accounting records at all. The medium body that performs accounting records shows that it only compiles profit and/or cash flow statements.

\section{Conclusion}

Based on the above discussion, shows microentities and small entities, as well as mediumsized entities, are still making an effortless accounting recording of daily accounting only (journals) and even most have not done minimum accounting records such as daily journals. Only one small entity performs complete accounting records in the form of a full financial statement. Thereby, the economic consequences of SAK EMKM implementation are still far from expectations and require a more intense form of socialization and mentoring to achieve the 
objectives that the issuance of SAK EMKM can be filled for all micro, small, and medium enterprises.

\section{References}

[1] Bing xin Du, Jiaxu Jiang, Xiuzhi JI, 2018, Research on The Developmnet of Management Accounting in SMEs Sizes Enterprises in China, Open Journal of Accounting, Vol. 7, 19-24

[2] Cull Robert, Kunt Asli Demirgu, Morduch Jonathan, 2009, Microfinance Tradeoffs: Regulation, Competition, and Financing, Policy Research Working Paper 5086, The World Bank

[3] Ikatan Akuntan Indonesia, 2016, SAK Entitas Mikro, Kecil dan Menengah, IAI

[4] Khavul Susanna, 2010, Microfinance: Creating Opportunities for the Poor?, The Academy and Management, University of Texas

[5] Olowe F.T., Modarewo O.A., and Babalola, O.A. 2913 Empirical Study of The Impact of Microfinance Bank on Small and Medium Growth in Nigeria, International Journal of Academic in Economics and Management Sciences, Vol2 No.6

[6] Sengupta Rajdeep and Aubuchon Craig P. 2008, The Microfinance Revolution: An Overview, Federal Reserve Bank of St. Louis Review

[7] Justice Stephen Tetteh Zotornie, 2017, A Study of Financial Accounting Practice of SMEs in Ho Municipality Ghana, International Journal of Academic Research in Business and Sosial Science, Vol.7 No.7

[8] Sengupta Rajdeep dan Aubuchon Craig P. 2008, The Microfinance Revolution: An Overview, Federal Reserve Bank of St. Louis Review

[9] Trombetta, Marcoe, Maria Luque Calvo, Pablo Casadio, 2917, Microfinance Institutions and Micro \& Small
Enterproses in Ghana, The Potential of The Missing Middle, Working Paper 